Pengaruh Penerapan Konservatisme... (Made Wahyu Adhiputra)

\title{
PENGARUH PENERAPAN KONSER VATISME AKUNTANSI DAN TINGKAT KEPEMILIKAN PADA KONFLIK BONDHOLDER-SHAREHOLDER DI BURSA EFEK INDONESIA
}

\author{
Made Wahyu Adhiputra \\ Program Manajemen, Fakultas Ekonomi, Universitas Mahendradatta \\ Email: madwahyuadhiputra@gmail.com
}

\begin{abstract}
ABSTRAK
Penelitian ini bertujuan untuk mengetahui pengaruh penerapan konservatisme akuntansi dan tingkat kepemilikan pada konflik bondholders-shareholders di Bursa Efek Indonesia. Populasi dalam penelitian ini adalah perusahaanperusahaan yang terdaftar di Bursa Efek Indonesia (BEI) tahun 2014-2016. Teknik penentuan sampel yang digunakan adalah purposive sampling sehingga didapat jumlah sampel sebanyak 40 perusahaan yang digunakan dalam analisis. Variabel bebas dalam penelitian ini adalah konservatisme akuntansi, kepemilikan institusional dan kepemilikan manajerial, dan variabel terikat adalah konflik bondholder-shareholder. Teknik analis is yang digunakan adalah regresi linier berganda. Berdasarkan hasil analisis dapat disimpulkan bahwa konservatisme akuntansi berpengaruh pada konflik bondholder-shareholder. Kepemilikan institusional tidak berpengaruh pada konflik bondholder-shareholder dan kepemilikan manajerial tidak berpengaruh pada konflik bondholder-shareholder.
\end{abstract}

\section{Kata kunci:}

teori agensi, konflik bondholder-shareholder, konservatisme akuntansi, kepemilikan institusional, kepemilikan manajemen.

\begin{abstract}
ABSTRACK
This study aims to determine the effect of accounting conservatism and ownership level on bondholdersshareholders in Indonesia Stock Exchange. Populations of this study are firms listed in Indonesian Stock Exchange in 2014-2016. The sampling technique used is purposive sampling therefore there are 40 firms used in analysis. Independent variable of this study is accounting conservatism, institutional ownership dan management's ownership, and dependent variable is bondholder-shareholder conflict. Linear regression analysis is used as analysis technique. Based on the analysis results is accounting conservatism affects bondholdershareholder conflict. Institutional ownership does not effects bondholder-shareholder conflict and management's ownership does not effects bondholder-shareholder conflict.
\end{abstract}

Keywords:

agency theory, bondholder-shareholder conflict, accounting conservatism, institutional ownership, management's ownership. 


\section{PENDAHULUAN}

\section{Latar Belakang}

Pasar modal adalah pasar dari berbagai instrumen keuangan jangka panjang yang dapat diperjualbelikan, baik dalam bentuk hutang (obligasi) maupun modal sendiri (saham) yang diterbitkan pemerintah dan perusahaan swasta (Husnan, 2004). Pasar modal telah menjadi bagian yang tidak terpisahkan dari kegiatan ekonomi di berbagai negara.

Perkembangan pasar modal yang pesat memiliki peran penting dalam meningkatkan pertumbuhan perekonomian karena pasar modal memiliki fungsi, yaitu fungsi ekonomi dan fungsi keuangan (Ang, 2007). Kehadiran pasar modal sangat penting bagi perusahaan dan investor. Para pihak yang memiliki kelebihan dana atau seringkali disebut dengan investor, dapat memanfaatkan pasar modal sebagai sarana untuk menyalurkan dana yang menganggur, sehingga diperoleh tambahan penghasilan berupa perolehan investasi dalam bentuk peningkatan nilai modal (capital gain) dan laba hasil usaha yang dibagikan (dividend) untuk investasi di pasar saham dan bunga (coupon) untuk investasi di pasar obligasi. Namun setiap instrumen investasi tersebut tentu memiliki karakteristik yang berbeda satu sama lain. Misalnya, melakukan investasi pada obligasi mungkin lebih tepat untuk dilakukan apabila investor berorientasi pada pendapatan tetap, sedangkan investasi dalam bentuk saham akan lebih tepat dilakukan investor yang berorientasi pertumbuhan (Haugen, 2007).

Perusahaan membutuhkan dana untuk membiayai operasi perusahaan, investasi dan kepentingan dana lainnya. Salah satu keputusan penting yang dihadapi manajemen berkaitan dengan kelangsungan operasi adalah keputusan pendanaan. Perusahaan dapat didanai dengan hutang dan ekuitas. Komposisi penggunaan hutang dan ekuitas tergambar dalam struktur modal. Manajemen harus mampu menghimpun dana baik yang bersumber dari dalam perusahaan maupun luar perusahaan secara efisien. Manajemen harus memperhatikan mengenai biaya modal. Biaya modal yang timbul dari keputusan pendanaan merupakan 
konsekuensi langsung atas keputusan pendanaan yang dilakukan oleh manajemen. Struktur modal yang meminimalkan biaya modal akan memaksimalkan harga saham perusahaan. Keputusan pendanaan yang dilakukan secara tidak cermat akan menimbulkan biaya tetap dalam bentuk biaya modal yang tinggi yang selanjutnya dapat berakibat pada rendahnya profitabilitas perusahaan (Prabansari dan Kusuma, 2005).

Penerbitan obligasi merupakan salah satu cara yang dilakukan oleh lembaga dan perusahaan untuk memperoleh sumber pembiayaan selain penjualan saham ke publik. Perusahaan yang menjual obligasi kepada masyarakat melalui pasar modal dapat memberikan imbal hasil berupa bunga coupon. Namun tentu saja sebelum melakukan penerbitan obligasi, perusahaan perlu melakukan perhitungan terlebih dahulu dengan membandingkan berbagai alternatif yang dapat ditempuh sebagai sumber pendanaan perusahaan. Karena setiap kebijakan yang ditempuh akan memberikan keuntungan dan kerugian (Jogiyanto, 2008).

Kebanyakan penelitian yang dilakukan di Indonesia berfokus pada kajian mengenai pasar saham. Masih sedikit penelitian yang secara khusus melakukan kajian pada obligasi di Bursa Efek Indonesia. Apalagi pada saat suku bunga diskonto (Sertifikat Bank Indonesia/Bank Indonesia Rate) makin menurun, di mana banyak perusahaan yang lebih memilih untuk menerbitkan obligasi dibandingkan menjual sahamnya kepada publik. Perusahaan enggan meminjam kredit ke bank karena suku bunga pinjaman tetap tinggi meskipun suku bunga diskonto makin menurun. Lain halnya dengan menerbitkan obligasi, perusahaan dapat menawarkan obligasi dengan nilai coupon yang hampir setara dengan tingkat diskonto.

Obligasi adalah surat utang jangka panjang yang diterbitkan oleh suatu lembaga/perusahaan di pasar modal dengan nilai nominal (nilai pari/par value) dan waktu jatuh tempo tertentu (Jogiyanto, 2008). Salah satu jenis obligasi yang diperdagangkan di pasar modal saat 
ini adalah obligasi kupon (coupon bond) dengan tingkat bunga tetap (fixed) selama masa berlaku obligasi (Astuti, 2003). Obligasi pendapatan tetap sebagai salah satu jenis obligasi memberikan pendapatan bunga secara rutin selama waktu berlakunya obligasi, sebagai keuntungan pertama. Keuntungan kedua adalah keuntungan atas penjualan obligasi (capital gain). Penerbitan obligasi merupakan salah satu keputusan penting yang diambil oleh pengelola perusahaan dalam rangka mendapatkan modal untuk kebutuhan usahanya. Pertimbangan utama yang mendasari pemilihan perusahaan swasta untuk menerbitkan obligasi sebagai alternatif pendanaan jangka panjang karena tingkat bunga obligasinya lebih rendah daripada tingkat bunga pinjaman bank (Nurfauziah dan Setyarini, 2004).

Berkaitan dengan masalah pendanaan, perusahaan dapat memperoleh dari dua sumber, pertama dari perusahaan itu sendiri, seperti penerbitan saham, dan laba ditahan; kedua dari luar perusahaan, berupa hutang kepada pihak ketiga yang sangat ditentukan oleh kebijakan pendanaan oleh satu perusahaan. Sebesar apapun sebuah perusahaan, agaknya kebijakan pendanaan dari luar perusahaan berupa hutang akan menjadi pilihan strategis. Namun, bukan berarti kebijakan ini tidak mengandung risiko. Ada kondisi yang dapat muncul dari kebijakan tersebut yaitu munculnya apa yang disebut dengan konflik keagenan. Konflik keagenan dapat memicu masalah asimetri informasi. Agen yang mempunyai informasi yang lebih banyak melakukan tindakan oportunistik yang menguntungkan dirinya sendiri. Dalam pihak prinsipal yang merasa memiliki informasi yang relatif lebih sedikit dibandingkan dengan pihak agen menuntut adanya kontribusi yang tinggi.

Pada kasus penentuan kebijakan leverage perusahaan, masalah yang muncul adalah konflik antara bondholder dan shareholder. Konflik ini terjadi karena adanya struktur penerimaan (pay off) dan tingkat risiko yang berbeda. Struktur penerimaan (pay off) bondholder memperoleh pendapatan yang tetap dari bunga dan pengembalian atas pinjamannya, sedangkan shareholder memperoleh pendapatan atas kelebihan kewajiban yang perlu 
dibayarkan kepada bondholder. Sedangkan dilihat dari tingkat risiko yang dihadapi, ketika shareholder melalui manajemen menjalankan aktivitas dengan risiko yang tinggi, maka tingkat risiko yang dihadapi bondholders jauh lebih tinggi daripada shareholders (Hanafi, 2005).

Tinggi rendahnya konflik keagenan dipengaruhi oleh tingkat peluang pertumbuhan (growth opportunities). Konflik ini muncul ketika perusahaan berhadapan dengan kesempatan investasi pada proyek dengan net present value (NPV) positif yang mensyaratkan penggunaan dana yang besar. Dalam kondisi free cash flow yang rendah dan asset in place yang kecil, untuk memenuhi dana guna meneruskan proyek yang ada, maka perusahaan cenderung mengambil hutang. Hal inilah yang memungkinkan terjadinya konflik antara bondholder dan shareholder. Konflik keagenan yang terjadi antara bondholder dan shareholder ini bukan berarti tidak dapat dicegah. Ada tiga mekanisme yang dapat ditawarkan yaitu dengan pengurangan jumlah hutang, mengambil hutang dengan jatuh tempo yang pendek dan kontrak hutang (covenant).

Kontrak hutang (covenant) di Indonesia dikenal dengan nama perjanjian perwaliamanatan yang harus dibuat oleh perusahaan pada saat mendaftarkan perusahaan di Bursa Efek Indonesia. Perjanjian perwaliamanatan dibuat antara emiten (perusahaan yang menerbitkan obligasi) dan Wali Amanat (UU No. 8 Th. 1995 tentang Pasar Modal). Wali Amanat berperan sebagai pihak yang mewakili kepentingan pemegang obligasi sekaligus memberikan perlindungan kepada para pemegang obligasi tersebut.

Sesuai dengan teori agensi, lazimnya konflik terjadi antara prinsipal atau pemilik (shareholder) dengan agensi atau manajemen. Konflik bondholder-shareholder berbeda dengan konflik agensi tersebut. Konflik terjadi karena adanya perbedaan kepentingan tentang pembayaran dividen. Shareholder menuntut perusahaan membagikan dividen yang tinggi sebagai hasil investasinya. Sebaliknya, bondholder juga menuntut perusahaan untuk 
tidak membayarkan dividen berlebihan agar tersedia jaminan/aset yang cukup untuk pembayaran hutang. Memang terjadi konflik antara manajemen dan pemegang saham mengenai kebijakan dividen sehingga manajemen berusaha untuk melakukan sesuatu agar dividen yang dibagikan menjadi relatif rendah (Widanaputra, 2007). Shareholder melalui serta bersama-sama dengan manajemen juga memiliki insentif untuk melakukan transfer kesejahteraan melalui pembayaran dividen. Kondisi tersebut menyebabkan bondholder kehilangan jaminan pelunasan hutang yang berpotensi meningkatkan risiko tidak terbayar sehingga akan memperbesar potensi konflik bondholder-shareholder. Semakin tinggi persentase dari dividen yang dibayarkan, semakin tinggi tingkat konservatisme akuntansi, berarti bahwa perusahaan dengan dividend payout ratio yang lebih besar akan lebih konservatif dalam melaporkan laba (Ratnadi, Sutrisno, Achsin dan Mulawarman, 2013).

Watts dan Zimmerman dalam Suharli (2009) mengajukan paradigma baru dalam penelitian akuntansi yang dikenal dengan Positive Accounting Theory dan menyatakan bahwa pemilihan kebijakan akuntansi dan karakteristik yang mendasari akuntansi keuangan tidak terlepas dari keberadaan perusahaan yang pada dasarnya merupakan suatu kumpulan dari kontrak. Dalam teori positif dibahas tiga hal, yaitu menjelaskan, mengawasi dan memprediksi. Scott (2009) menyebutkan bahwa positive accounting theory is concerned with predicting such actions as the choices of accounting policies by firm managers and how managers will respond to proposed new accounting standards. Teori akuntansi positif berhubungan dengan prediksi suatu keputusan dalam prinsip akuntansi oleh manajer perusahaan dan bagaimana manajer akan memberikan respon terhadap standar akuntansi yang baru. Teori akuntansi positif mengasumsikan bahwa manajer mempunyai sifat yang rasional seperti investor dan manajer akan memilih kebijakan akuntansi yang memberikan keuntungan bagi dirinya sendiri. 
Menurut Ahmed et.al (2002) dan Sari (2004), untuk mengefektifkan kontrak hutang, bondholder mensyaratkan perusahaan yang berhadapan dengan konflik bondholdershareholder menggunakan akuntansi konservatif. Konservatisme akuntansi dapat membatasi pembayaran dividen yang dilakukan manajemen, kecuali dalam kondisi pembayaran dividen sangat rendah. Menurut Hille (2011), dalam kondisi pembayaran dividen rendah, penggunaan akuntansi konservatif tidak berpengaruh dan atau mampu mengatasi konflik bondholder-shareholder. Penggunaan akuntansi konservatif ditandai dengan munculnya akrual negatif yang dihasilkan dari penundaan pengakuan pendapatan dan mempercepat pengakuan kerugian (Givoly dan Hayn, 2000). Perusahaan akan lebih cepat mengakui biayabiaya dan menunda pengakuan terhadap pendapatan-pendapatan. Akibatnya nilai perusahaan turun karena rendahnya laba dan berpengaruh pada keterbatasan fleksibilitas pendanaan (Lee, 2010).
Menurut teori konservatisme, akuntan harus melaporkan nilai terendah dari beberapa nilai yang mungkin untuk aktiva dan pendapatan serta nilai tertinggi untuk kewajiban dan beban. Akuntansi konservatif bermanfaat untuk mengatasi permasalahan keagenan terkait keputusan investasi manajer, meningkatkan efisiensi kontrak hutang, fasilitasi pengawasan kontrak, dan mengurangi biaya pemeriksaan (Lara et al.; 2007, dan Ahmed et al.; 2002). Konservatisme berperan dengan melaporkan laba yang rendah sehingga dapat menekan insentif manajer dan shareholder untuk melakukan transfer kesejahteraan dengan cara pembagian dividen berlebih. Bondholder juga akan meminta perusahaan menggunakan akuntansi konservatif ketika konflik bondholdershareholder semakin tinggi. Perusahaan yang dikelola oleh non manajer-pemilik lebih konservatif dibandingkan dengan perusahaan yang dikelola oleh manajer-pemilik (Widanaputra, 2007).

Penelitian Gray et al. (2001) mengenai konservatisme akuntansi, modal dan jumlah 
tenaga kerja dan profitabilitas menunjukkan

bahwa konservatisme akuntansi berpengaruh pada pengungkapan tanggung jawab sosial perusahaan. Dahlia dan Siregar (2008) meneliti mengenai pengaruh konservatisme akuntansi terhadap kinerja perusahaan. Penelitian ini mengukur konservatisme akuntansi dengan menggunakan indikator dari Global Reporting Initiatives (GRI) pada perusahaan yang tercatat di BEI pada tahun 2005 dan 2006. Hasil penelitian menemukan konservatisme akuntansi berpengaruh terhadap kinerja keuangan perusahaan tetapi tidak berpengaruh pada kinerja pasar.

Nurlela dan Islahuddin (2008) meneliti mengenai pengaruh konservatisme akuntansi terhadap nilai perusahaan dengan prosentase kepemilikan manajemen sebagai variabel moderating. Penelitian ini mengambil sampel perusahaan pada sektor non finansial tahun 2005 dengan metode purposive sampling. Hasil penelitian menunjukkan pengungkapan konservatisme akuntansi tidak berpengaruh pada nilai perusahaan dan kepemilikan manajemen tidak mampu memoderasi hubungan antara pengungkapan konservatisme akuntansi terhadap nilai perusahaan.

Retno dan Priantinah (2012) meneliti mengenai pengaruh konservatisme akuntansi dan pengungkapan CSR terhadap nilai perusahaan pada perusahaan di BEI periode 2007-2010. Hasil penelitian menunjukkan konservatisme akuntansi berpengaruh positif terhadap nilai perusahaan tetapi pengungkapan CSR tidak berpengaruh terhadap nilai perusahaan. Tija dan Setiawati (2012) meneliti pengaruh pengungkapan konservatisme akuntansi pada nilai perusahaan pada industri perbankan di Indonesia. Hasil penelitian adalah pengungkapan konservatisme akuntansi tidak berpengaruh pada nilai perusahaan. Agustina (2012) meneliti pengaruh konservatisme akuntansi dan pengungkapan CSR terhadap nilai perusahaan pada perusahaan yang tercatat di BEI pada tahun 2007-2010. Penelitian ini menemukan konservatisme akuntansi dan pengungkapan CSR berpengaruh positif pada nilai perusahaan. 
Astarini (2011) menemukan bahwa struktur kepemilikan berpengaruh signifikan terhadap konservatisme akuntansi, sedangkan debt covenant dan pertumbuhan tidak berpengaruh signifikan terhadap konservatisme akuntansi. Persamaan penelitian ini dengan penelitian sebelumnya adalah sama-sama meneliti konservatisme akuntansi / akuntansi konservatif. Perbedaannya adalah penelitian ini juga menguji pengaruh kepemilikan institusional dan kepemilikan manajerial terhadap konflik bondholder-shareholder selain variabel konservatisme akuntansi.

Kepemilikan manajerial, sebagai salah satu manifestasi dari tata kelola yang baik, diharapkan dapat membatasi tindakan oportunistik manajer dan shareholder untuk memaksimalkan kepentingannya. Dengan demikian, konflik bondholder-shareholder dapat direduksi. Dukungan kepemilikan manajerial terhadap penggunaan akuntansi konservatif dapat menekan konflik bondholdershareholder. Menurut teori struktur kepemilikan perusahaan, manajer dan pemegang saham memiliki kepentingan yang sama terhadap nilai perusahaan dan bertentangan dengan kepentingan bondholder. Oleh karena itu, mereka cenderung memaksimumkan kesejahteraannya dengan melakukan transfer kesejahteraan dari bondholder.

Menurut teori kontrak hutang, untuk membatasi adanya transfer kesejahteraan dan menyelaraskan kepentingan berbagai pihak dalam perusahaan, maka perlu adanya mekanisme kontrak hutang. Mekanisme kontrak yang efisien menekankan pada penggunaan kebijakan akuntansi konservatif. Ahmed et al. (2002) berpendapat bahwa kontrak akan lebih efektif dengan menggunakan akuntansi konservatif. Midiastuty dan Mas'ud (2003) juga menyimpulkan bahwa konflik dapat diatasi dengan meningkatkan kepemilikan manajerial dan kepemilikan institusional.

Pada dasarnya akuntansi merupakan suatu proses untuk menyediakan informasi keuangan suatu organisasi mengenai posisi keuangan dan hasil usaha perusahaan yang dapat dipergunakan oleh pihak-pihak yang 
berkepentingan dalam proses pengambilan keputusan. Penyajian informasi keuangan tersebut harus memiliki syarat kehati-hatian dalam mengukur aktiva dan laba karena aktivitas dan bisnis dilingkupi suatu ketidakpastian. Sehingga pada prinsipnya konservatisme akuntansi diimplementasikan dalam keadaan jika terdapat sesuatu peningkatan aktiva yang belum terealisasi, maka kejadian itu belum bisa diakui. Namun, mengakui adanya penurunan aktiva walaupun kejadian tersebut belum terealisasi.

Menurut Bahaudin dan Pro vita (2011), bagi pihak manajemen prinsip akuntansi yang berlaku umum (generally accepted accounting principles) memberikan fleksibilitas dalam menentukan metode maupun estimasi akuntansi yang dapat digunakan. Fleksibilitas tersebut akan mempengaruhi perilaku manajer dalam melakukan pencatatan akuntansi dan pelaporan keuangan perusahaan. Dalam kondisi keraguraguan, seorang manajer harus menerapkan prinsip akuntansi yang bersifat konservatif. Beberapa peneliti menyebutkan bahwa telah terjadi peningkatan konservatisme standar akuntansi secara global. Peningkatan itu disebabkan oleh meningkatnya tuntutan hukum, sehingga auditor dan manajer cenderung melindungi dirinya dengan selalu melaporkan angka-angka konservatif di dalam laporan keuangannya (Givoly dan Hayn, 2000).

Beberapa peneliti menyatakan bahwa konservatisme akuntansi memiliki peranan dalam teori keagenan untuk penentuan praktik yang paling efisien yang bisa membatasi konflik atau masalah keagenan. Praktik di perusahaan ternyata agen dalam aktifitasnya seringkali tidak sesuai dengan kontrak kerja yang dibuat dengan pemegang saham yaitu agen lebih cenderung untuk meningkatkan kesejahteraannya sendiri. Hal ini dapat terjadi karena munculnya asimetri informasi antara agen dan pemegang saham, sehingga agen berpeluang untuk melaksanakan praktik ini dengan cara memanipulasi laporan keuangan. Konservatisme akuntansi dapat berperan dalam teori keagenan untuk mencegah adanya asimetri informasi dengan cara membatasi agen dalam melakukan praktik manipulasi laporan keuangan. 
Sampai saat ini, prinsip konservatisme masih dianggap sebagai prinsip yang kontroversial. Terdapat banyak kritikan yang muncul, namun ada pula yang mendukung penerapan prinsip konservatisme. Apabila metode yang digunakan dalam penyusunan laporan keuangan berdasarkan prinsip akuntansi yang sangat konservatif, maka hasilnya cenderung bias dan tidak mencerminkan kenyataan. Di sisi lain, konservatisme akuntansi bermanfaat untuk menghindari perilaku oportunistik manajer berkaitan dengan kontrakkontrak yang menggunakan laporan keuangan sebagai media kontrak (Watts, 2003). Lafond dan Watts (2006) juga menjelaskan bahwa laporan keuangan yang konservatif dapat mencegah adanya asimetri informasi (information asymmetry) dengan cara membatasi manajemen dalam melakukan manipulasi laporan keuangan. Menurutnya, laporan keuangan yang konservatif dapat mengurangi biaya keagenan.

\section{Rumus an Masalah}

Berdasarkan latar belakang yang telah diuraikan di atas, maka yang menjadi pokok permasalahan dalam penelitian ini adalah sebagai berikut:

1. Bagaimana pengaruh konservatisme akuntansi pada konflik bondholdershareholder di Bursa Efek Indonesia?

2. Bagaimana pengaruh kepemilikan institusional pada konflik bondholdershareholder di Bursa Efek Indonesia?

3. Bagaimana pengaruh kepemilikan manajerial pada konflik bondholdershareholder di Bursa Efek Indonesia?

\section{TINJAUAN TEORI}

\section{Teori Keagenan (Agency Theory)}

Jensen dan Meckling (1976) menyatakan bahwa teori keagenan mendeskripsikan pemegang saham sebagai prinsipal dan manajemen sebagai agen. Manajemen merupakan pihak yang dikontrak oleh pemegang saham untuk bekerja demi kepentingan pemegang saham. Untuk itu manajemen 
diberikan sebagian kekuasaan untuk membuat keputusan bagi kepentingan terbaik pemegang saham. Oleh karena itu, manajemen wajib mempertanggungjawabkan semua upayanya kepada pemegang saham. Karena unit analisis dalam teori keagenan adalah kontrak yang melandasi hubungan antara prinsipal dan agen, maka penentuan kontrak yang paling efisien yang mendasari hubungan antara prinsipal dan agen. Untuk memotivasi agen maka prinsipal merancang suatu kontrak agar dapat mengakomodasi kepentingan pihak-pihak yang terlibat dalam kontrak keagenan. Kontrak yang efisien adalah kontrak yang memenuhi dua faktor, yaitu: (1) Agen dan prinsipal memiliki informasi yang simetris artinya baik agen maupun prinsipal memiliki kualitas dan jumlah informasi yang sama sehingga tidak terdapat informasi tersembunyi yang dapat digunakan untuk keuntungan dirinya sendiri; (2) Risiko yang dipikul agen berkaitan dengan imbal jasanya adalah kecil yang berarti agen mempunyai kepastian yang tinggi mengenai imbalan yang diterimanya.
Hubungan keagenan merupakan suatu kontrak antara prinsipal dengan agen, pada intinya adanya pemisahan antara kepemilikan (investor) dan pengelolaan (manajer/agen). Adanya pemisahan kepemilikan oleh prinsipal dengan pengendalian oleh agen dalam suatu organisasi cenderung menimbulkan konflik keagenan di antara prinsipal dan agen. Jensen dan Meckeling (1976) dan Watts dan Zimmerman (1986) menyatakan bahwa laporan keuangan yang dibuat dengan angka-angka akuntansi diharapkan dapat meminimalkan konflik di antara pihak-pihak yang berkepentingan. Laporan keuangan yang dilaporkan oleh agen sebagai pertanggungjawaban kinerjanya, digunakan oleh prinsipal untuk menilai, mengukur, dan mengawasi sampai sejauh mana agen bekerja untuk meningkatkan kesejahteraannya dan sebagai dasar pemberian kompensasi kepada agen. Biaya keagenan yang timbul akibat adanya konflik kepentingan ini adalah biaya pengawasan (monitoring costs), biaya penjaminan (bonding costs), dan rugi residual (residual loss). Untuk 
mengurangi biaya keagenan dapat ditempuh beberapa mekanisme yaitu melalui kepemilikan saham perusahaan bagi manajer, penggabungan sumber pendanaan dari pinjaman dan ekuitas, serta pembagian dividen (Crutchley dan Hansen, 1989 dalam Yasa, 2010).

Konservatisme dapat dijelaskan dari perspektif teori keagenan. Menurut teori keagenan, manajer (agent) memiliki tindakan kesempatan untuk memaksimalkan kesejahteraannya sendiri dengan mengorbankan kepentingan pemegang saham, debtholders, dan pihak pengontrakan lainnya (principals). Teori tersebut menjelaskan perusahaan merupakan nexus of contract, yakni tempat bertemunya kontrak antar berbagai pihak yang berpotensi menimbulkan konflik kepentingan (Juanda, 2007). Pandangan teori keagenan di mana terdapat pemisahan antara pihak agen dan prinsipal yang mengakibatkan munculnya potensi konflik dapat mempengaruhi kualitas laba yang dilaporkan. Pihak manajemen yang mempunyai kepentingan tertentu akan cenderung menyusun laporan laba yang sesuai dengan tujuannya dan bukan demi untuk kepentingan prinsipal. Dalam kondisi seperti ini diperlukan suatu mekanisme pengendalian yang dapat mensejajarkan perbedaan kepentingan antara kedua belah pihak dengan mengaplikasikan prinsip konservatisme akuntansi.

\section{Konservatisme}

Konservatisme merupakan salah satu prinsip yang digunakan dalam akuntansi. Statement of Financial Accounting Concept No.8 dari serangkaian publikasi di FASB untuk akuntansi dan pelaporan keuangan dimaksudkan untuk menetapkan tujuan-tujuan dan konsepkonsep fundamental yang akan menjadi dasar untuk pengembangan akuntansi keuangan dan pedoman pelaporan. Sari (2004) menyatakan konservatisme adalah reaksi hati-hati untuk menghadapi ketidakpastian dalam mencoba memastikan bahwa ketidakpastian dan risiko pada situasi bisnis telah dipertimbangkan. Basu (1997) mendefinisikan konservatisme sebagai praktik mengurangi laba (mengecilkan aktiva bersih) dalam merespons berita buruk (bad news), tetapi tidak meningkatkan laba 
(meninggikan aktiva bersih) dalam merespons berita baik (good news).

Konservatisme telah menjadi prinsip akuntansi yang banyak dianut oleh para akuntan sejak abad ke-15 dan semakin popular penggunaannya dalam tiga dekade terakhir. Konservatisme sebagai reaksi hati-hati (prudent reaction) menghadapi ketidakpastian. Hal ini dilakukan untuk memastikan bahwa ketidakpastian dan resiko yang melekat pada situasi bisnis telah cukup dipertimbangkan. Terdapat pro dan kontra sehubungan dengan penerapan prinsip konservatisme. Pengkritik konservatisme menyatakan bahwa prinsip ini mengakibatkan laporan keuangan menjadi bias sehingga tidak dapat dijadikan sebagai alat untuk mengevaluasi resiko perusahaan. Pendapat ini didukung oleh Monahan (1999) yang menyatakan bahwa semakin tinggi konservatisme maka nilai buku yang dilaporkan akan semakin bias. Di lain pihak, Ahmed et al. (2002) sebagai pendukung konservatisme berpendapat bahwa konservatisme dapat mengurangi konflik antara bondholder-shareholder seputar kebijakan dividen. Pembayaran dividen yang terlalu tinggi akan menimbulkan ancaman bagi debtholders karena akan mengurangi aktiva yang seharusnya tersedia untuk pelunasan utang. Mengatasi masalah ini, tindakan yang biasa dilakukan adalah dengan melakukan pembatasan pembagian dividen berdasarkan perolehan laba perusahaan. Untuk itu dibutuhkan penyajian laba yang konservatif demi membatasi pembayaran dividen yang terlalu tinggi serta penyajian aktiva yang konservatif untuk memberikan gambaran kepada debtholders tentang ketersediaan aktiva untuk pembayaran hutang. Watts (2003) sebagai pendukung konservatisme lainnya berpendapat bahwa konservatisme merupakan salah satu karakteristik yang sangat penting dalam mengurangi biaya agensi dan meningkatkan kualitas informasi laporan keuangan sehingga pada akhirnya akan meningkatkan nilai perusahaan dan harga sahamnya. Para pemegang saham mempunyai harapan agar manajemen bertindak atas kepentingan mereka. Untuk itu dibutuhkan pengawasan seperti pemeriksaan laporan keuangan serta pembatasan 
keputusan yang dapat diambil manajemen. Biaya yang dikeluarkan untuk kegiatan pengawasan tersebut disebut sebagai biaya agensi. Peneliti lain yang mendukung konservatisme adalah LaFond dan Watts (2006). Lafond dan Watts (2006) berpendapat bahwa laporan keuangan yang mengaplikasikan prinsip konservatisme dapat mengurangi kemungkinan manajer melakukan manipulasi laporan keuangan serta mengurangi biaya agensi yang muncul sebagai akibat dari asimetri informasi.

$$
\text { Watts (2003) mendefinisikan }
$$

konservatisme sebagai perbedaan verifiabilitas yang diminta untuk pengakuan laba dibandingkan rugi. Watts juga menyatakan bahwa konservatisme akuntansi muncul dari insentif yang berkaitan dengan biaya kontrak, litigasi, pajak dan politik yang bermanfaat bagi perusahaan untuk mengurangi biaya keagenan dan mengurangi pembayaran yang berlebihan kepada pihak-pihak seperti manajer, pemegang saham, pengadilan dan pemerintah. Selain itu, konservatisme juga menyebabkan understatement terhadap laba dalam periode kini yang dapat mengarahkan pada overstatement terhadap laba pada periode-periode berikutnya, sebagai akibat understatement terhadap biaya pada periode tersebut. Sedangkan, Suwardjono (2010) mendefinisikan konservatisme sebagai sikap atau aliran (mazhab) dalam menghadapi ketidakpastian untuk mengambil tindakan atau keputusan yang terburuk dari ketidakpastian tersebut.

Penman dan Zhang (2002) menjelaskan konservatisme akuntansi merupakan suatu pemilihan metode dan estimasi akuntansi yang menjaga nilai buku dari net assets relatif rendah. Mereka mencontohkan definisi tersebut dalam penggunaan metode pencatatan persediaan. Penggunaan metode Last In First Out (LIFO) dalam menilai persediaan pada saat nilai persediaan meningkat adalah salah satu contoh penerapan akuntansi konservatisme. Metode LIFO dikatakan lebih konservatif karena metode ini mengakibatkan nilai persediaan lebih rendah dibandingkan dengan First In First Out (FIFO) dan average cost method pada saat nilai persediaan mengalami peningkatan. 
Richardson dan Tinaikar (2003) dalam

Kiryanto dan Edy (2006), menunjukkan bahwa ada dua jenis laba konservatisme, yaitu: (1) exante conservatism atau news-independent conservatism; dan (2) ex-post conservatism atau news dependent conservatism. Ex-ante conservatism atau news-independent conservatism berkaitan dengan kebijakankebijakan yang mengurangi laba secara independen dari kejadian-kejadian ekonomi saat ini, bahkan apabila pengeluaran-pengeluaran tersebut berkaitan secara positif dengan harapan aliran kas di masa yang akan datang.

$$
\text { Ex-post conservatism atau news }
$$

dependent conservatism menggambarkan lebih tepat waktu untuk pengakuan laba terhadap bad news dari pada good news. Secara umum, prinsip akuntansi ini menghendaki penghapusan dengan segera untuk mengakui bad news terhadap persediaan, goodwill, ketidakpastian kerugian dan sebabnya. Menurut Kiryanto dan Edy (2006), penggunaan dari ex-post conservatism atau news dependent conservatism ini menghasilkan slope koefisien regresi laba terhadap returns yang lebih tinggi untuk perusahaan-perusahaan dengan negatif returns (bad news) daripada positif returns (good news).

$$
\text { Watts (2003) mendefinisikan }
$$

konservatisme sebagai prinsip kehati-hatian dalam pelaporan keuangan di mana perusahaan tidak terburu-buru dalam mengakui dan mengukur aktiva dan laba serta segera mengakui kerugian dan hutang yang mempunyai kemungkinan akan terjadi. Penerapan prinsip ini mengakibatkan pilihan metode akuntansi ditujukan pada metode yang melaporkan laba atau aktiva lebih rendah serta melaporkan hutang lebih tinggi. Dengan demikian, pemberi pinjaman akan menerima perlindungan atas resiko menurun (downside risk) dari neraca yang menyajikan aset bersih understatement dan laporan keuangan yang melaporkan berita buruk secara tepat waktu. Givoly dan Hayn (2000) mendefinisikan konservatisme sebagai pengakuan awal untuk biaya dan rugi serta menunda pengakuan untuk pendapatan dan keuntungan. Konservatisme akuntansi 
merupakan suatu pemilihan metode dan estimasi akuntansi yang menjaga nilai buku dari net assets relatif rendah (Penman dan Zhang, 2002). Penggunaan metode LIFO dalam menilai persediaan di saat nilai persediaan meningkat adalah salah satu contoh penerapan akuntansi konservatisme. LIFO dikatakan lebih konservatif karena metode LIFO mengakibatkan nilai persediaan lebih rendah dibandingkan dengan FIFO dan average cost method pada saat nilai persediaan mengalami peningkatan. Memilih untuk membebankan pengeluaran research and development $(R \& D) \quad$ daripada mengkapitalisasikan pengeluaran $\mathrm{R} \& \mathrm{D}$ sebagai aset dan kemudian diamortisasi merupakan contoh lain dari penerapan metode konservatisme. Pemilihan metode depresiasi yang secara konsisten menggunakan estimasi umur aset yang pendek juga mengindikasikan penerapan konservatisme dalam laporan keuangan. Dengan kata lain, perusahaan membebankan depresiasi atau penyusutan melebihi economic depreciation, sehingga nilai aset yang disusutkan relatif lebih rendah dari seharusnya. Hal ini yang menyebabkan metode penyusutan seperti ini juga mengindikasikan konservatisme.

\section{Kepemilikan Institutional.}

Kepemilikan institusional juga diidentifikasi mempengaruhi konflik bondholdershareholder. Kepemilikan institusional berperan sebagai pengawas yang efektif terhadap manajemen perusahaan karena menguasai mayoritas saham dan memiliki sumber daya lebih besar dibandingkan dengan pemegang saham. Hartzell dan Starks (2003) menemukan bahwa institusi memiliki peranan dalam melakukan pengawasan terhadap manajemen perusahaan terkait masalah agensi. Shareholder berperan dan mempunyai kewenangan memilih dan mengangkat, mengkompensasi dan memecat manajer sehingga dianggap efisien untuk menyamakan tujuan manajer dengan tujuan pemegang saham. Shareholder institusional dapat memanfaatkan kapasitas yang dimilikinya untuk meningkatkan kesejahteraan pihaknya sendiri dengan mengabaikan pihak lain (Haryono, 2005). Besarnya kepemilikan institusional 
memberikan tekanan kepada manajer yang ingin terlihat baik di depan pemegang saham dengan memperlihatkan kinerjanya. Salah satu cara agar kinerja manajer dianggap bagus dengan melunasi hutang perusahaan dan membagikan dividen terus menerus untuk menarik investasi masuk. Shareholder dapat memaksa manajemen membayar dividen dengan memilih pejabat dalam perusahaan yang menawarkan kebijakan dividen sesuai harapan shareholder dan menggunakan alasan mencari tambahan pendanaan dari luar yang lebih besar untuk menarik investasi masuk (La Porta et al, 2000). Semakin besar kepemilikan institusional berarti semakin besar konflik bondholder shareholder karena investor institusional mengharapkan return yang tinggi dalam bentuk dividen dan capital gain (Jensen, 1986). Sesuai dengan yang dilakukan oleh Midiasruty dan Mas'ud (2003), menyimpulkan bahwa kepemilikan institusional berpengaruh terhadap konflik agensi yakni konflik yang terjadi antara bondholder dan shareholder.

\section{Kepemilikan Manajerial}

Mengacu pada teori agensi yang mengasumsikan masing-masing pihak berkonflik untuk memaksimalkan kepentingannya, maka semakin besar kepemilikan manajerial berarti semakin besar konflik bondholder-shareholder karena setiap manajer yang memiliki kepemilikan manajerial berusaha memaksimalkan keuntungan bagi dirinya untuk memperoleh dividen. Kepemilikan manajerial dipandang dapat menyelaraskan potensi perbedaan kepentingan dalam permasalahan keagenan. Midiastuty dan Mas'ud (2003) membuktikan bahwa kepemilikan manajerial berpengaruh terhadap konflik agensi. Sedangkan Fauz dan Rosidi (2007) belum berhasil membuktikan bahwa kepemilikan manajerial berpengaruh terhadap konflik bondholder-shareholder. Shareholder dapat memaksa manajemen perusahaan membayar dividen yaitu dengan memilih pejabat dalam perusahaan yang menawarkan kebijakan dividen sesuai harapan shareholder dan menggunakan alasan mencari tambahan pendanaan dari luar yang lebih besar sehingga perusahaan secara 
terus menerus membayarkan dividen untuk menarik investasi masuk (La Porta et al, 2000).

\section{Konflik Bondholder Shareholder}

\section{Konflik bondholder-shareholder}

terjadi karena perbedaan kepentingan mengenai kebijakan pembayaran dividen akibat adanya pendanaan investasi dari hutang. Bondholder meminta perusahaan untuk tidak membayarkan dividen berlebih agar tersedia kecukupan aktiva minimum untuk pembayaran hutang, sedangkan shareholder menuntut adanya pembayaran dividen terus menerus jumlahnya besar (Ahmed etal, 2002; dan Sari, 2004).

$$
\text { Dalam konflik bondholder }
$$

shareholder, diasumsikan shareholder memilih dan mengangkat, mengkompensasi dan memecat manajer sehingga dianggap efisien untuk menyamakan tujuan manajer dengan tujuan pemegang saham (Haryono, 2005). Menurut Almilia (2007), hutang memberikan insentif bagi manajer dan shareholder untuk melakukan tindakan-tindakan yang dapat mengurangi nilai hutang dan memperbesar nilai ekuitasnya melalui keputusan-keputusan investasi dan keputusan- keputusan pendanaan. Keputusan investasi dapat mempengaruhi bagian manajer dan shareholder atas nilai perusahaan, melalui mekanisme dispersion effect dan repayment effect. Pada dispersion effect, jika terdapat 2 (dua) proyek investasi yang mempunyai dispersi yang berbeda, perbedaan dispersi tersebut akan mempengaruhi nilai pasar hutang. Pengarah dispersi terhadap nilai pasar hutang disebabkan adanya perbedaan probabilitas debt default. Nilai pasar hutang akan lebih besar bagi proyek investasi yang mempunyai dispersi yang lebih rendah.

$$
\text { Nilai perusahaan merupakan }
$$
penjumlahan nilai hutang dan nilai ekuitas, sehingga dengan nilai perusahaan tetap, kenaikan nilai hutang akan mengurangi nilai ekuitas. Nilai ekuitas menunjukkan bagian kesejahteraan manajer dan shareholder. Manajer dan shareholder cenderung memilih proyek investasi yang mempunyai dispersi yang besar (sehingga nilai hutang turun). Manajer dan shareholder dapat melakukan transfer kesejahteraan dari bondholder dengan menyatakan akan mengambil proyek yang dispersinya kecil 
sehingga nilai hutang yang diperoleh akan tinggi, tetapi kemudian manajer dan shareholder memilih proyek investasi yang dispersinya besar, sehingga manajer dan faktor yang diidentifikasi berpengaruh terhadap terjadinya konflik bondholder-shareholder. Menurut Watt (2002), diperlukan adanya kontrak utang untuk mengatasi konflik. Sementara menurut Begley dan Freedman (2004), diperlukan adanya batasan terhadap kebijakan pendanaan dan investasi. Bondholder pada umumnya menuntut penggunaan akuntansi konservatif terhadap kebijakan dividen untuk memastikan tidak adanya pemberian dividen berlebih dan distribusi aktiva. Penerapan akuntansi konservatif juga diidentifikasi berdampak pada penurunan konflik karena biaya keagenan akan semakin rendah (Kwon, 2005). Perusahaan yang berhadapan dengan tingginya konflik bondholdershareholder terkait kebijakan dividen cenderung menggunakan akuntansi konservatif (Ahmed et $a l$, 2002). Penggunaan akuntansi konservatif juga dapat meningkatkan efektivitas dari kontrak hutang (Li dan Mehta, 2010). Tujuannya memastikan pembatasan pembayaran dividen, pengembalian pinjaman dan tersedianya aktiva untuk pelunasan hutang. Pada sisi lain, Hille (2011) tidak menemukan hubungan antara konflik bondholder-shareholder dengan konservatisme akuntansi yang diakibatkan pembayaran dividen rendah.

\section{Hipotesis Penelitian}

Beberapa peneliti menyatakan bahwa konservatisme akuntansi memiliki peranan dalam teori keagenan untuk penentuan praktik yang paling efisien yang bisa membatasi konflik atau masalah keagenan. Praktik di perusahaan ternyata agen dalam aktivitasnya seringkali tidak sesuai dengan kontrak kerja yang dibuat dengan pemegang saham yaitu agen lebih cenderung untuk meningkatkan kesejahteraannya sendiri. Hal ini dapat terjadi karena munculnya asimetri informasi antara agen dan pemegang saham, sehingga agen berpeluang untuk melaksanakan praktik ini dengan cara memanipulasi laporan keuangan. Konservatisme akuntansi dapat berperan dalam teori keagenan untuk mencegah adanya asimetri informasi dengan cara 
membatasi agen dalam melakukan praktik manipulasi laporan keuangan.

Sampai saat ini prinsip konservatisme masih dianggap sebagai prinsip yang kontroversial. Terdapat banyak kritikan yang muncul, namun ada pula yang mendukung penerapan prinsip konservatisme. Indrayati (2010) menyatakan bahwa kritikan terhadap penerapan prinsip konservatisme antara lain konservatisme dianggap sebagai kendala yang akan mempengaruhi laporan keuangan. Apabila metode yang digunakan dalam penyusunan laporan keuangan berdasarkan prinsip akuntansi yang sangat konservatif, maka hasilnya cenderung bias dan tidak mencerminkan kenyataan. Di sisi lain, konservatisme akuntansi bermanfaat untuk menghindari perilaku oportunistik manajer berkaitan dengan kontrakkontrak yang menggunakan laporan keuangan sebagai media kontrak (Watts, 2003). Kontrak tersebut terkait dengan kepemilikan earnings response coefficient pada perusahaan manufaktur dan non-manufaktur (kecuali perbankan) dari tahun 1996 hingga 2000, menemukan bukti bahwa akrual diskresioner dengan konservatisme laporan keuangan berhubungan signifikan tetapi lemah. Sedangkan hubungan earnings response coefficient dengan konservatisme laporan keuangan, khususnya bahwa earnings response coefficient laporan yang optimis lebih besar dibandingkan earnings response coefficient laporan yang konservatif. Hasil pengujian juga menunjukkan bahwa earnings response coefficient laporan yang cenderung persisten optimis lebih tinggi dibandingkan earnings response coefficient laporan yang cenderung persisten konservatif.

Widya (2005) melakukan penelitian dengan judul "Analisis Faktor-faktor Yang Mempengaruhi Pilihan Perusahaan Terhadap Akuntansi Konservatif." Dalam penelitiannya, Widya menggunakan struktur kepemilikan, kos politis, kontrak utang dan pertumbuhan sebagai variabel bebas. Sedangkan variabel terikatnya adalah konservatisme. Hasil dari penelitian tersebut menunjukkan bahwa konsentrasi struktur kepemilikan, besarnya kos politis dan 
pertumbuhan penjualan merupakan faktor-faktor

yang mempengaruhi pilihan perusahaan terhadap

akuntansi konservatif. Semakin besar konsentrasi

struktur kepemilikan perusahaan terhadap modal,

serta semakin besar kos politis yang dikeluarkan

perusahaan, maka perusahaan tersebut cenderung untuk memilih strategi akuntansi konservatif. Di sisi lain, penelitian tersebut menunjukkan bahwa leverage bukan merupakan faktor yang mempengaruhi pilihan perusahaan terhadap akuntansi konservatif.

Ahmed dan Duellman (2007) menguji mengenai karakteristik dewan terhadap konservatisme akuntansi menemukan bukti bahwa inside directors berhubungan negatif signifikan dengan konservatisme akuntansi yang diukur dengan ukuran akrual, sedangkan outside directors berhubungan positif. Ukuran dewan menunjukkan hasil yang tidak signifikan dengan konservatisme akuntansi yang diukur dengan ukuran akrual, sedangkan kepemilikan institusional dan ukuran perusahaan sebagai variabel kontrol berhubungan negatif dan tidak signifikan.
$\mathrm{H}_{1}$ : $\quad$ konservatisme akuntansi berpengaruh positif terhadap konflik bondholder-shareholder pada corporate bonds di Bursa Efek Indonesia.

Besarnya kepemilikan institusional memberikan tekanan kepada manajer yang ingin terlihat baik di depan pemegang saham dengan memperlihatkan kinerjanya. Salah satu cara agar kinerja manajer dianggap bagus dengan melunasi hutang perusahaan dan membagikan dividen terus menerus untuk menarik investasi masuk. Shareholder dapat memaksa manajemen membayar dividen dengan memilih pejabat dalam perusahaan yang menawarkan kebijakan dividen sesuai harapan shareholder dan menggunakan alasan mencari tambahan pendanaan dari luar yang lebih besar untuk menarik investasi masuk (La Porta et al., 2000). Semakin besar kepemilikan institusional berarti semakin besar konflik bondholder-shareholder karena investor institusional mengharapkan return yang tinggi dalam bentuk dividen dan capital gain (Jensen, 1986). Sesuai dengan penelitian yang dilakukan oleh Midiastuty dan Mas'ud (2003), 
menyimpulkan bahwa kepemilikan institusional berpengaruh terhadap konflik agensi yakni konflik yang terjadi antara bondholder dan shareholder.

$$
\mathrm{H}_{2} \text { : kepemilikan institusional }
$$
berpengaruh positif terhadap konflik bondholder-shareholder pada corporate bonds di Bursa Efek Indonesia.

Kepemilikan manajerial dipandang dapat menyelaraskan potensi perbedaan kepentingan dalam permasalahan keagenan. Midiastuty dan Mas'ud (2003) membuktikan bahwa kepemilikan manajerial berpengaruh terhadap konflik agensi, sedangkan Fauz dan Rosidi (2007) belum berhasil membuktikan bahwa kepemilikan manajerial berpengaruh terhadap konflik bondholder-shareholder. Shareholder dapat memaksa manajemen membayar dividen dengan memilih pejabat dalam perusahaan yang menawarkan kebijakan dividen sesuai harapan shareholder (La Portal al, 2000).

Menurut Lafond dan Rouchowdhury (2007), kepemilikan manajerial merupakan presentase kepemilikan saham perusahaan oleh direktur perusahaan dibandingkan dengan jumlah saham perusahaan yang beredar secara keseluruhan. Hubungan antara kepemilikan manajerial dan konservatisme terjadi pada saat perusahaan akan melakukan investasi yang akan berpengaruh terhadap laba perusahaan. Hal ini disebabkan konservatisme akuntansi akan membuat perusahaan lebih mengakui kerugian dan menunda pengakuan keuntungan yang dapat berpengaruh terhadap penilaian kinerja manajer. Ahmed dan Duelhnan (2007) melakukan penelitian tentang pengaruh insider ownership dan independent board director terhadap konservatisme akuntansi. Kepemilikan saham perusahaan oleh pihak insider diharapkan dapat mengurangi masalah keagenan antara manajer dan pemegang saham. Hasil penelitian ini menunjukkan bahwa persentase kepemilikan insider berpengaruh positif terhadap konservatisme akuntansi. Independent board director berpengaruh signifikan terhadap konservatisme akuntansi dengan size, leverage, dan institusional ownership sebagai variabel kontrol. 
$\mathrm{H}_{3}$ : kepemilikan manajerial yang digunakan dalam penelitian ini diperoleh berpengaruh positif terhadap konflik dari website www.idx.co.id.

bondholder-shareholder pada corporate Populasi dan Sampel

bonds di Bursa Efek Indonesia.

Populasi dalam penelitian ini adalah seluruh perusahaan-perusahaan yang

METODE RISET

\section{Jenis dan Sumber Data}

Berdasarkan jenisnya, data yang digunakan dalam penelitian ini adalah data kuantitatif yaitu data dalam bentuk angka-angka atau data kualitatif yang diangkakan (Sugiyono, 2007:13). Data kuantitatif dalam penelitian ini adalah laporan keuangan tahunan auditan perusahaan-perusahaan yang menerbitkan obligasi korporasi yang terdaftar di Bursa Efek Indonesia periode 2014-2016. Berdasarkan sumbernya, data yang digunakan dalam penelitian ini adalah data sekunder, yaitu data yang diperoleh secara tidak langsung dari perusahaan yang diteliti.

Sampel yang digunakan dalam penelitian ini adalah perusahaan-perusahaan yang menerbitkan obligasi korporasi yang terdaftar di Bursa Efek Indonesia periode 2014-2016. Data menerbitkan obligasi korporasi yang terdaftar di Bursa Efek Indonesia periode 2014-2016. Sampel adalah bagian dari jumlah maupun karakteristik yang dimiliki oleh populasi tersebut (Sugiyono, 2007:73). Pemilihan sampel penelitian didasarkan pada metoda purposive sampling, yaitu teknik pengambilan sampel dengan pertimbangan atau kriteria tertentu (Sugiyono, 2007:78). Kriteria yang dipertimbangkan dalam pengambilan sampel penelitian ini adalah perusahaan yang terdaftar dan menerbitkan obligasi korporasi secara berturut-turut selama periode pengamatan yaitu tahun 2014-2016. 
Tabel 1.

\section{Proses Pemilihan Sampel}

\begin{tabular}{|c|c|c|}
\hline No & Kriteria & Jumlah \\
\hline 1 & $\begin{array}{l}\text { Perusahaan yang terdaftar dan } \\
\text { menerbitkan obligasi korporasi } \\
\text { secara berturut-turut dari tahun } \\
\text { 2014-2016 }\end{array}$ & 43 \\
\hline 2 & $\begin{array}{l}\text { Perusahaan yang terdaftar dan } \\
\text { tidak menerbitkan obligasi } \\
\text { korporasi secara berturut-turut } \\
\text { dari tahun 2014-2016 }\end{array}$ & 3 \\
\hline & Jumlah Sampel Akhir & 40 \\
\hline & Tahun Pengamatan & 3 \\
\hline & Jumlah Pengamatan & 120 \\
\hline
\end{tabular}

Sumber: BEI, data diolah (2017)

\section{Definisi Ope rasional Variabel}

Berikut definisi operasional variabel yang digunakan:

a. Konservatisme merupakan sebuah tindakan penuh kehati-hatian yang dilakukan oleh perusahaan ketika menyusun laporan keuangan. Perusahaan yang menganut akuntansi konservatif cenderung memiliki akrual negatif disebabkan laba bersih yang dihasilkan lebih kecil dan kas bersih yang diperoleh dari aktivitas operasi.
Konservatisme diukur dengan model pengukuran menurut Lara et al. (2007) dengan rumus:

$$
\mathrm{KONS}_{\mathrm{i}, \mathrm{t}}=\sum \frac{\mathrm{NI}_{\mathrm{i}, \mathrm{t}-\mathrm{x}}+\mathrm{B}^{\mathrm{B}} \text { Dep }_{\mathrm{i}, \mathrm{t}-\mathrm{x}}+\mathrm{CFO}_{\mathrm{i}, \mathrm{t}-\mathrm{x}}}{\text { T.Aktiva }} \mathrm{i,t- \textrm {x }}
$$

b. Kepemilikan institusional adalah kepemilikan obligasi perusahaan oleh institusi di luar perusahaan. Pengukuran terhadap kepemilikan institusional melihat pada persentase obligasi, di mana membagi jumlah obligasi yang dimiliki pihak institusi dari luar perusahaan dengan total obligasi yang beredar. Rumus yang digunakan sesuai penelitian Midiastuty dan Mas'ud (2003):

\section{Kepemilikan Institusional =} $\frac{\text { Jumlah Obligasi Dimiliki Institusional }}{\text { Jumlah Obligasi Beredar }} \times 100 \%$

c. Kepemilikan manajerial adalah kepemilikan obligasi perusahaan oleh direksi maupun komisaris perusahaan. Kepemilikan manajerial diukur berdasarkan persentase obligasi yang dimiliki manajemen dengan rumus sebagaimana digunakan Midiastuty dan Mas'ud (2003) sebagai berikut: 
Journal of Management
and Business Roview 15, No. 1, $2018: 54-89$

Kepemilikan Manajerial=

$\frac{\text { Jumlah Obligasi Dimiliki Manajerial }}{\text { Jumlah Obligasi Beredar }} x 100 \%$

d. Konflik Bondholder-Shareholder

(KONF), konflik ini terjadi di seputar kebijakan

pembayaran hutang perusahaan. Bondholder sebagai pihak yang memberi pinjaman kepada perusahaan menuntut agar perusahaan tidak membagikan dividen berlebihan di atas nilai yang telah ditentukan sedangkan shareholder menuntut agar perusahaan membagikan dividen yang besar. Konflik diukur menggunakan proksi tingkat pembayaran hutang dengan membagi jumlah hutang yang dibayarkan termasuk hutang obligasi dengan total aktiva perusahaan. Jika perusahaan membayarkan hutang dengan level yang rendah, maka konsentrasi bondholder terhadap pembayaran hutang berkurang. Konflik diukur dengan menggunakan formula sebagaimana digunakan Ahmed et al. (2002) sebagai berikut:

Tingkat Pembayaran Hutang=

$\frac{\text { Hutang yang Dibayarkan }}{\text { Total Aktiva Perusahaan }} \times 100 \%$

Total Aktiva Perusahaan

\section{Alat Analisis}

Analisis data dalam penelitian ini dilakukan dengan menggunakan regresi linear berganda. Sebelum model regresi digunakan untuk menguji hipotesis, tentunya model tersebut harus bebas dari gejala asumsi klasik karena model yang baik harus memenuhi kriteria Best Linear Unbiased Estimator (BLUE). Analisis menggunakan bantuan program SPSS versi 22 for windows. Model analisis regresi linear berganda digunakan untuk mengetahui pengaruh variabel bebas terhadap variabel terikat dengan persamaan sebagai berikut:

$$
\mathrm{KONF}=\alpha+\beta 1 \mathrm{KONS}+\beta 2 \mathrm{INSOWN}+
$$

$\beta 3 \mathrm{MANOWN}+\mathrm{e}$

\section{PEMBAHASAN}

\section{Statis tik Deskriptif}

Statistik deskriptif dalam penelitian memberikan gambaran atau deskripsi suatu data yang dilihat dari nilai rata-rata (mean), standar deviasi, nilai maksimum dan minimum. Konservatisme akuntansi diukur dengan model pengukuran menurut Lara et al. (2007), memiliki 
nilai rata-rata 0,068817 dengan standar deviasi 0,1939205. Pengukuran terhadap kepemilikan institusional melihat pada persentase obligasi, di mana membagi jumlah obligasi yang dimiliki pihak institusi dari luar perusahaan dengan total obligasi yang beredar. Rumus yang digunakan sesuai penelitian Midiastuty dan Mas'ud (2003). Memiliki nilai rata-rata 0,252544 dengan standar deviasi 0,3023347 .

Kepemilikan manajerial diukur berdasarkan persentase obligasi yang dimiliki manajemen dengan rumus sebagaimana digunakan Midiastuty dan Mas'ud (2003). Memiliki nilai rata-rata 0,016702 atau 1,6702 persen dengan standar deviasi 0,0328285 . Konflik bondholder-shareholder diukur menggunakan proksi tingkat pembayaran hutang dengan membagi jumlah hutang yang dibayarkan dengan total aktiva perusahaan. Konflik bondholder-shareholder diukur dengan menggunakan formula sebagaimana digunakan Ahmed et al. (2002). Memiliki nilai rata-rata sebesar7,575165 dengan standar deviasi 2,6672859 .
Statistik deskriptif masing-masing variabel disajikan pada Tabel 2.

Tabel 2.

Statistik Des kriptif

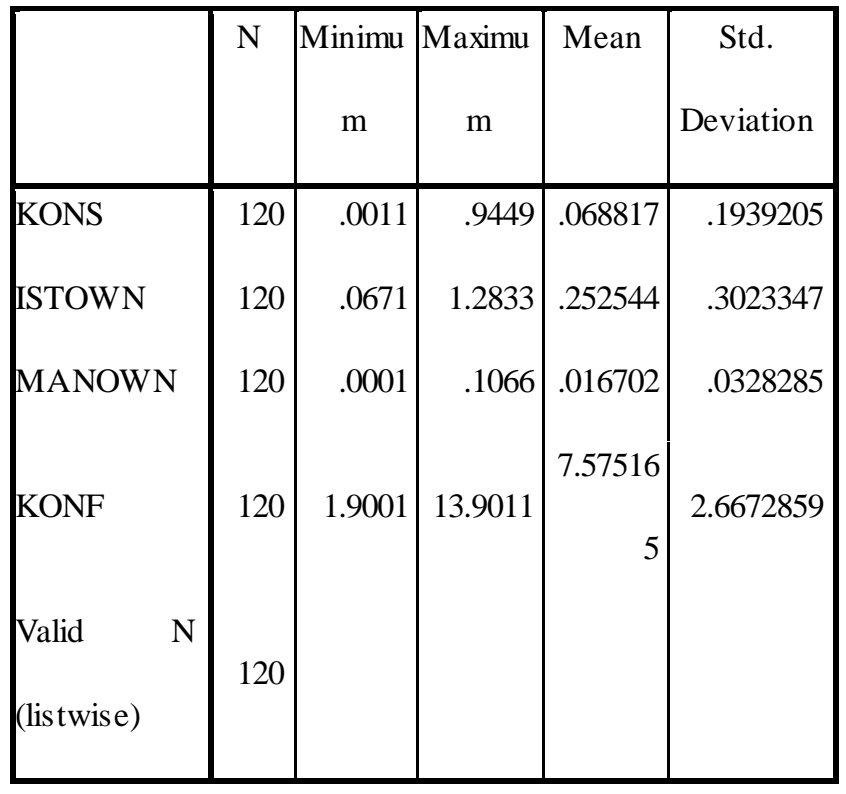

Sumber: Data diolah (2017)

\section{Hasil Uji Asumsi Klasik}

Uji normalitas dan uji heteroskedastisitas sudah dilakukan dan tidak ada masalah.

\section{Hasil Analis is Regresi}

\section{Hasil Uji Kelayakan Model}

Hasil uji kelayakan model dilakukan dengan uji $\mathrm{F}$ yang menunjukkan nilai signifikansi sebesar 0,000 lebih kecil dari 0,05 maka model regresi dianggap layak. Tabel 3 berikut ini menunjukkan pengujian selengkapnya. 
Tabel 3.

Hasil Uji Kelayakan Model

\begin{tabular}{|l|r|r|l|l|l|}
\hline Model & Sumof & df & Mean & F & Sig. \\
& Squares & & Square & & \\
\hline Regression & 66.286 & 3 & 22.095 & 3.285 & $.000^{\mathrm{b}}$ \\
1 Residual & 780.329 & 116 & 6.727 & & \\
Total & 846.615 & 119 & & & \\
\hline
\end{tabular}

a. Dependent Variable: KONF

b. Predictors: (Constant), MANOWN, KONS, ISTOWN

Sumber : Data diolah (2017)

\section{Koefisien Determinasi}

Besarnya koefisien determinasi pada model regresi ditunjukkan dengan nilai adjusted $R^{2}$. Berdasarkan hasil pengujian yang ditunjukkan pada Tabel 4, nilai adjusted $R^{2}$ adalah sebesar 0,054 yang berarti variabilitas variabel dependen yang dapat dijelaskan oleh variabel independen adalah sebesar $5,4 \%$, sedangkan sisanya sebesar 94,6\% dijelaskan oleh variabel-variabel lain di luar model penelitian.

Tabel 4.

Koefisien Determinasi

\begin{tabular}{|l|l|r|r|r|}
\hline Model & $\mathrm{R}$ & $\mathrm{R}$ & $\begin{array}{c}\text { Adjusted } \mathrm{R} \\
\text { Square }\end{array}$ & $\begin{array}{c}\text { Std. Error of the } \\
\text { Estimate }\end{array}$ \\
\hline 1 & $.280^{\mathrm{a}}$ & .078 & .054 & 2.5936409 \\
\hline
\end{tabular}

a. Predictors: (Constant), MANOWN, KONS, ISTOWN

b. Dependent Variable: KONF

Sumber : Data diolah (2017)

\section{Hasil Uji Hipotesis}

Hasil pengujian hipotesis ditunjukkan

oleh Tabel 5 di bawah ini.

Tabel 5.

Hasil Uji Hipotes is

\begin{tabular}{|c|c|c|c|c|c|}
\hline \multirow[t]{2}{*}{ Model } & \multicolumn{2}{|c|}{$\begin{array}{c}\text { Unstandardized } \\
\text { Coefficients }\end{array}$} & $\begin{array}{c}\text { Standardized } \\
\text { Coefficients }\end{array}$ & \multirow[t]{2}{*}{$\mathrm{t}$} & \multirow[t]{2}{*}{ Sig } \\
\hline & B & $\begin{array}{l}\text { Std. } \\
\text { Error }\end{array}$ & Beta & & \\
\hline (Constant) & 7.264 & .341 & & 21.286 & .00 \\
\hline KONS & 2.825 & 1.237 & .205 & 2.284 & .02 \\
\hline ISTOWN & 1.314 & .803 & .149 & 1.636 & .10 \\
\hline MANOWN & -12.863 & 7.358 & -.158 & -1.748 & .08 \\
\hline
\end{tabular}

a. Dependent Variable: KONF

Sumber : Data diolah (2017)

Berdasarkan Tabel 5 di atas dapat

diestimasi model regresi sebagai berikut:

$\mathrm{Y}=7,264+2,825 \mathrm{X}_{1}+1,314 \mathrm{X}_{2}-12,863 \mathrm{X}_{3}+\mathrm{e}$

Berdasarkan persamaan tersebut,

diketahui nilai konstanta besarnya 7,264 mengandung arti jika variabel konservatisme akuntansi $\left(\mathrm{X}_{1}\right)$, kepemilikan institusional $\left(\mathrm{X}_{2}\right)$ dan kepemilikan manajerial $\left(\mathrm{X}_{3}\right)$ tidak berubah, maka konflik bondholder-shareholder (Y) tidak mengalami perubahan atau sama dengan 7,264. $\beta 1=2,825 ; \quad$ berarti apabila variabel konservatisme akuntansi $\left(\mathrm{X}_{1}\right)$ meningkat sebesar 1 (satu) satuan, maka akan mengakibatkan 
peningkatan pada konflik bondholdershareholder (Y) sebesar 2,825 satuan, dengan asumsi variabel bebas yang lain dianggap konstan. $\beta 2=1,314$; berarti apabila variabel kepemilikan institusional $\left(\mathrm{X}_{2}\right)$ meningkat sebesar 1 (satu) satuan, maka akan mengakibatkan peningkatan pada konflik bondholdershareholder (Y) sebesar 1,314, dengan asumsi variabel bebas yang lain dianggap konstan $\beta 3=-$ 12,863; berarti apabila variabel kepemilikan manajerial $\left(\mathrm{X}_{3}\right)$ meningkat sebesar 1 (satu) satuan, maka akan mengakibatkan penurunan pada konflik bondholder-shareholder (Y) sebesar 12,863 satuan, dengan asumsi variabel bebas yang lain dianggap konstan.

\section{1) Pengujian Hipotesis Pertama $\left(\mathrm{H}_{1}\right)$}

Hipotesis pertama menyatakan bahwa konservatisme akuntansi berpengaruh positif terhadap konflik bondholder-shareholder pada corporate bonds di Bursa Efek Indonesia. Pengaruh konservatisme akuntansi $\left(\mathrm{X}_{1}\right)$ pada konflik bondholder-shareholder dapat dilihat dari signifikansi sebesar 0,024 lebih kecil dari tingkat signifikansi 0,05 maka $\mathrm{H}_{0}$ ditolak dan $\mathrm{H}_{1}$ diterima. Hasil pengujian hipotesis pertama $\left(\mathrm{H}_{1}\right)$ diperoleh konservatisme akuntansi berpengaruh positif pada konflik bondholder-shareholder. Hal ini menunjukkan bahwa untuk meminimalkan konflik bondholder-shareholder mampu dipengaruhi oleh variabel konservatisme akuntansi. Konservatisme akuntansi berpengaruh positif pada konflik bondholder-shareholder pada corporate bonds di Bursa Efek Indonesia. Jadi, berdasarkan hasil tersebut dapat dinyatakan bahwa hipotesis pertama $\left(\mathrm{H}_{1}\right)$ didukung.

\section{2) Pengujian Hipotesis Kedua $\left(\mathrm{H}_{2}\right)$}

Hipotesis kedua menyatakan bahwa kepemilikan institusional berpengaruh positif terhadap konflik bondholder-shareholder pada corporate bonds di Bursa Efek Indonesia. Pengaruh kepemilikan institusional $\left(\mathrm{X}_{2}\right)$ pada konflik bondholder-shareholder dapat dilihat dari signifikansi sebesar 0,105 lebih besar dari tingkat signifikansi 0,05 maka $\mathrm{H}_{0}$ diterima dan $\mathrm{H}_{2}$ ditolak. Hasil pengujian hipotesis kedua $\left(\mathrm{H}_{2}\right)$ diperoleh kepemilikan institusional berpengaruh negatif pada konflik bondholder-shareholder. Hal ini menunjukkan bahwa untuk meminimalkan 
konflik bondholder-shareholder tidak mampu dipengaruhi oleh variabel kepemilikan institusional. Kepemilikan institusional tidak berpengaruh pada konflik bondholdershareholder pada corporate bonds di Bursa Efek Indonesia. Jadi, berdasarkan hasil tersebut dapat dinyatakan bahwa hipotesis kedua $\left(\mathrm{H}_{2}\right)$ tidak didukung.

3) Pengujian Hipotesis Ketiga $\left(\mathrm{H}_{3}\right)$ Hipotesis ketiga menyatakan bahwa kepemilikan manajerial berpengaruh positif terhadap konflik bondholder-shareholder pada corporate bonds di Bursa Efek Indonesia. Pengaruh kepemilikan manajerial $\left(\mathrm{X}_{3}\right)$ pada konflik bondholder-shareholder dapat dilihat dari signifikansi sebesar 0,083 lebih besar dari tingkat signifikansi 0,05 , maka $\mathrm{H}_{0}$ diterima dan $\mathrm{H}_{3}$ ditolak. Hasil pengujian hipotesis ketiga $\left(\mathrm{H}_{3}\right)$ diperoleh kepemilikan manajerial berpengaruh negatif pada konflik bondholder-shareholder. Hal ini menunjukkan bahwa untuk meminimalkan konflik bondholder-shareholder tidak mampu dipengaruhi oleh variabel kepemilikan manajerial. Kepemilikan manajerial tidak berpengaruh pada konflik bondholder-shareholder pada corporate bonds di Bursa Efek Indonesia. Jadi, berdasarkan hasil tersebut dapat dinyatakan bahwa hipotesis ketiga $\left(\mathrm{H}_{3}\right)$ tidak didukung.

\section{Konservatisme akuntansi berpengaruh positif terhadap konflik bondholder- shareholder pada corporate bonds di Bursa} Efek Indonesia.

Hasil penelitian ini menunjukkan bahwa konservatisme akuntansi berpengaruh positif pada konflik bondholder-shareholder. Penelitian ini menunjukkan bahwa semakin tinggi atau rendah konservatisme akuntansi yang dilakukan perusahaan berpengaruh pada konflik bondholder-shareholder. Hasil penelitian ini mendukung penelitian yang dilakukan oleh Ahmed dan Duellman (2007), yang menemukan bahwa konservatisme akuntansi berpengaruh positif pada konflik bondholder-shareholder. 
Kepemilikan institusional berpengaruh negatif terhadap konflik bondholdershareholder pada corporate bonds di Bursa

\section{Efek Indonesia.}

Hasil penelitian ini menunjukkan bahwa kepemilikan institusional berpengaruh negatif pada konflik bondholder-shareholder. Penelitian ini menunjukkan bahwa semakin tinggi atau rendah kepemilikan institusional yang dilakukan perusahaan tidak berpengaruh pada konflik bondholder-shareholder. Hasil penelitian ini tidak mendukung penelitian yang dilakukan oleh Midiastuty dan Mas'ud (2003), yang menemukan bahwa kepemilikan institusional berpengaruh positif pada konflik bondholder-shareholder.

Kepemilikan manajerial berpengaruh negatif terhadap konflik bondholdershareholder pada corporate bonds di Bursa

\section{Efek Indonesia.}

Hasil penelitian ini menunjukkan bahwa kepemilikan manajerial berpengaruh negatif pada konflik bondholder-shareholder. Penelitian ini menunjukkan bahwa semakin tinggi atau rendah kepemilikan manajerial yang dilakukan perusahaan tidak berpengaruh pada konflik bondholder-shareholder. Hasil penelitian ini tidak mendukung penelitian yang dilakukan oleh Fauz dan Rosidi (2007) dan Ahmed dan Duelhnan (2007) yang menemukan kepemilikan manajerial berpengaruh positif pada konflik bondholder-shareholder.

\section{KESIMPULAN DAN SARAN}

\section{Kesimpulan}

Berdasarkan hasil analisis dan pembahasan, dapat diambil beberapa simpulan sebagai berikut:

1. Konservatisme akuntansi berpengaruh positif pada konflik bondholdershareholder.

2. Kepemilikan institusional berpengaruh negatif pada konflik bondholdershareholder.

3. Kepemilikan manajerial berpengaruh negatif pada konflik bondholdershareholder. 


\section{Saran}

Saran-saran yang dapat disampaikan

bagi penelitian selanjutnya adalah sebagai

berikut:

1. Penelitian selanjutnya sebaiknya dilakukan dengan menggunakan sampel semua penerbit obligasi di Bursa Efek Indonesia sehingga diharapkan hasil analisis yang lebih mencerminkan kondisi pasar modal Indonesia.

2. Keterbatasan dalam penelitian ini adalah nilai Adjusted $R$-squared yang kecil.
Dimana penelitian dengan data sekunder, terutama pasar modal. Banyak dipengaruhi oleh variabel lain, baik faktor internal maupun eksternal. Penelitian selanjutnya dapat menambah variabel lain yang dapat mempengaruhi konflik bondholder-shareholder. Seperti operating uncertainty, dividend policy, leverage, konflik kepentingan, risiko litigasi, tipestrategi, kurs, inflasi dan jumlah uang yang beredar. 
Pengaruh Penerapan Konservatisme... (Made Wahyu Adhiputra)

\section{DAFTAR PUSTAKA}

Ahmed, A. Billings, B. Morton, R. dan Stanford-Harris, M. 2002. The Role of Accounting Conservatism in Mitigating Bondholder-Shareholder Conflicts over Dividend Policy and in Reducing Debt Costs. The Accounting Review. Vol. 77, No. 4, October 2002, pp: 867-890.

Ahmed, AS., Duellman, S., 2007. Accounting Conservatism and Board of Director Characteristics: An Empirical Analysis. http//www.ssrn.com.

Agustina, S. 2012. Pengaruh Konservatisme Akuntansi dan Pengungkapan Corporate Social Responsibility terhadap Nilai Perusahaan. Tesis. Universitas Negeri Padang.

Almilia L.S., 2007. "Pengaruh Environmental Performance dan Environmental Disclosure terhadap Economic Performance". Proceedings The 1st Accounting Conference. Depok.

Astarini, Dwi. 2011. Analisis Faktor-Faktor Yang Mempengaruhi Pilihan Perusahaan Terhadap Konservatisme Akuntansi. Tesis. Universitas Pembangunan Nasional "Veteran", Yogyakarta.

Astuti. 2003. Pengujian Size Hypothesis dan Debt/Equity Hypothesis yang Mempengaruhi Tingkat Konservatisma Laporan Keuangan Perusahaan dengan Tehnik Analisis Multinomial Logit. Jurnal Bisnis dan Akuntansi.

Astuti, Januar. 2002. Factors Affecting Income Smoothing Listed Companies in Singapore. Journal of Accounting and Business Research. Autumn, pp: 291-301.

Badera, I Dewa Nyoman. 2008. Pengaruh Kesesuaian Hubungan Corporate Governance dengan Budaya Korporasi Terhadap Kinerja Perusahaan. Disertasi. Universitas Gadjah Mada, Yogyakarta.

Bahaudin, Ahmad, dan Provita W., 2011. Mekanisme Corporate Governance terhadap Konservatisme Akuntansi di Indonesia.Dinamika Sosial Ekonomi.Mei, Volume 7 Nomor 1.

Basu, S. 1997. The Conservatism Principle and The Asymetric Timelines of Earnings. Journal of Accounting and Economics.29 (February): 1-51.

Begley, J dan Freedman, R. 2004. The Changing Role of Accounting Number in Public Lending Agreements. Accounting Horizon. Vol 18, No 2, June 2004, pp: 81-96.

Crutchley, C. E., \& Hansen, R. S. 1989. A Test of The Agency Theory of Managerial Ownership, Corporate Leverage and Corporate Dividends. Financial Management. 18(4), pp: 36-46. http://dx.doi.org/10.2307/3665795.

Dahlia, L. Siregar, V. S. 2008. Pengaruh Konservatisme Akuntansi terhadap Kinerja Perusahaan (Studi Empiris pada Perusahaan yang Tercatat di Bursa Efek Indonesia pada Tahun 2005 dan 2006). Simposiun Nasional Akuntansi XI. Pontianak.

Fauz, A. dan Rosidi. 2007. Pengaruh Aliran Kas Bebas, Kepemilikan Managerial, Kepemilikan Institusional, Kebijakan Hutang dan Collateral Asset terhadap Kebijakan Dividen. Jurnal Ekonomi dan Manajemen. Volume 8, Nomor 2, Juni 2007.

Financial Accounting Standard Board. 1996. Qualitative Characteristics of Accounting Information.Statement of Financial Accounting Concept no.8. John Wiley \& Sons, Inc, New York.

Givoly, D., dan Hayn, C. 2000. The Changing Time-Series Properties of Earnings, Cash Flows and Accruals: Has Financial Reporting Become More Conservative? Journal of Accounting and Economics.

Gray, R. Javad, M. Power, D. M, Sinclair, C. D. 2001. The Conservatism Principle, And Corporate Characteristic: A Research Note and Extension. Journal of Business Finance and Accounting. Vol 28 No 3, pp: 327-356.

Haugen, 2007. Base-dependence in Reduplication. Morphology. Vol 21, pp: 1-29.

Haryono, S. 2005. Struktur Kepemilikan dalam Bingkai Teori Keagenan. Jurnal Akuntansi dan Bisnis. Vol 5 No.1, Pebruari 2005.

Hille, J., C. 2011. Accounting Conservatism: The Association Between Bondholder-shareholder Conflicts Over Dividend Policy and Accounting Conservatism, The Effect on the Cost of Debt and the 
Influence of the Implementation of IFRS in 2005. Working Paper. Department of Accounting, Auditing \& Control. Erasmus School of Economics.

Haniati, Fitriany. 2010. Pengaruh Konservatisme terhadap Asimetri Informasi dengan Menggunakan Beberapa Model Pengukuran Konservatisme. Simposium Nasional Akuntansi 13. Purwokerto.

Hartzell, J. and L. Starks. 2003. Institutional Investors and Executive Compensation. Journal of Finance. Vol. 52, pp: 2351-2374.

Hellman, N. 2007. Accounting Conservatism under IFRS.Accounting in Europe 5. No. 2, pp: 71-100.

Hidayati, E. E, 2010. Analisis Pengaruh Konservatisme AkuntansiTerhadap PBV Perusahaan Manufaktur yang Listing di BEI Periode 2005-2007’. Tesis. Semarang: Universitas Diponegoro.

Husaini dan Saiful. 2003. Pengaruh Penerbitan Obligasi Terhadap Risiko dan Return Saham. Jurnal Manajemen dan Bisnis. Vol. 5 No. 1, pp: 35-46.

Indanning, Rizka Putri dan Ratih Handayani. 2009. Pengaruh Kepemilikan Manajerial, Kepemilikan Institusional, Dividen, Pertumbuhan Perusahaan, Free Cash Flow dan Profitabilitas terhadap Kebijakan Utang Perusahaan. Jurnal Bisnis dan Akuntansi. Vol. 11, No. 3, hal: 189-207.

Indrayati, Martha Rizki. 2010. Pengaruh Karakteristik Dewan Komisaris Terhadap Tingkat Konservatisme Akuntansi. Tesis. Universitas Diponegoro. Semarang.

Jensen, Michael C. dan W.H. Meckling. 1976. Theory of the Firm: Managerial Behavior, Agency Cost and Ownership Structure. Journal of Financial Economics. Vol. 3, pp: 305-360.

Jensen, 1986. The Takeover Controversy: Analysis and Evidence. Managerial Economics Research Center, Working Paper. No. 86-01, University of Rochester, March 1986.

Juanda, 2007. Pengaruh Risiko Litigasi dan Tipe Strategi terhadap Hubungan Antara Konflik Kepentingan dan Konservatisma Akuntansi. Disertasi. Universitas Gadjah Mada.

Kiryanto, dan Edy Suprianto. 2006. Pengaruh Moderasi Size terhadap Hubungan Laba Konservastisma dengan Neraca Konservatisma.Simposium National Akuntansi IX, Padang.

Kusumadilaga, R. 2010. Pengaruh Konservatisme Akuntansi Terhadap Nilai Perusahaan Dengan Profitabilitas Sebagai Variabel Moderating. Tesis. Semarang: Universitas Diponegoro.

Kwon, Y. 2005. Accounting Conservatism and Managerial Incentives. Management Science. Vol. 51, No. 11, November 2005, pp: 1626-1632.

Lafond, Watts. 2006. The Information Role of Conservative Financial statements. http://papers.ssrn.com.

Lara, J., Osma, B., dan Penalva, F. 2007. Accounting Conservatism and Corporate governance. Springer Science+Business Media, LLC 2007.

Lasdi. 2009. Pengujian Determinan Konservatisme Akuntansi. Jurnal Akuntansi Kontemporer. Vol. I (1).

La Porta, Rafael, Florencio Lopez-de-Silanes, and Andrei Shleifer, 2000, Corporate ownership around the world, Journal of Finance 54, 471-517.

Lee, J. 2010. The Role of Accounting Conservatism in Firms' Financial Decisions. Kellogg School of Management Northwestern University.

Li, L., dan Mehta, M. 2010. The Relation between Firm Characteristics and Dividend Covenants. Social Science Research Network.

Mayasari, 2010. Konservatisme Akuntansi, Value Relevance dan Discretionary Accruals: Implikasi Empiris Model Feltham Ohlson (1996). Simposium Nasional Akuntansi IV.

Midiastuty., P.P., dan Mas'ud. 2003. Analisis Hubungan Mekanisme Corporate governance dan Indikasi Manajemen Laba. Simposium Nasional Akuntansi VI, Surabaya.

Monahan, S. J., 1999. Conservatism, Growth and the Role of Accounting Numbers in the Fundamental Analysis Process.Review of Accounting Studies. Vol. 10, pp: 227-260.

Mulyadi, M. S dan Anwar, Y. 2010. Impact of Accounting ConservatismToward Firm Value and Profitability. The Business Review. Cambridge Vol 19 No 2 Summer 2012. 
Ni Made Dwi Ratnadi, Sutrisno T, M. Achsin dan Aji Dedi Mulawarman. 2013. The Effect of Shareholders' Conflict over Dividend Policy on Accounting Conservatism : Evidence from Public Firms in Indonesia. Research Journal of Finance and Accounting Vol 4.

Nurfauziah dan Setyarini. 2004. "Pengaruh Karakteristik Dewan Sebagai Salah Satu Mekanisme Corporate Governance Terhadap Konservatisme Akuntansi di Indonesia”. Jurnal Akuntansi dan Auditing, II (2004), Universitas Diponegoro.

Nurlela dan Islahuddin. 2008. Pengaruh Konservatisme Akuntansi terhadap Nilai Perusahaan Dengan Prosentase Kepemilikan Manajemen Sebagai Variabel Moderating (Studi Empiris pada Perusahaan yang Terdaftar di BEJ). Simposium Nasional Akuntansi XI Pontianak2008.

Penman, S. H., dan X. J. Zhang. 2002. Accounting Conservatism: The Quality of Earnings and Stock Returns. The Accounting Review. Vol.77 (2). pp: 237-264.

Prabansari, Yuke dan Hadri Kusuma. 2005. Faktor - faktor yang Memengaruhi Struktur Modal Perusahaan Manufaktur Go Publik di Bursa Efek Jakarta. Sinergi, Edisi khusus on Finance. Hal: 1 - 15.

Ramadhani, L. S. Hadiprajitno, B. 2012. Pengaruh Konservatisme Akuntansi Terhadap Nilai Perusahaan dengan Prosentasi Kepemilikan Manajemen sebagai Variabel Moderating pada Perusahaan Manufaktur yang Terdaftar di BEI. Jurnal Akuntansi \& Auditing Volume 8.

Retno, R. D dan Priantinah, D. 2012.Pengaruh Konservatisme Akuntansi dan Pengungkapan Corporate Social Responsibility terhadap Nilai Perusahaan (Studi Empiris pada Perusahaan yang Terdaftar di BEI periode 2007-2010. Jurnal Nominal. Vol I No 1 Tahun 2012.

Richardson, G. and S. Tinaikar. 2003. Accounting Based Valuation Models. What Have We Learned ?. Working Paper. University of Toronto.

Sari, D. 2004. Hubungan Antara Konservatisme Akuntansi dengan Konflik Bondholders-Shareholders Seputar Kebijakan Dividen dan Peringkat Obligasi Perusahaan. Simposium Nasional Akuntansi VII, Bali.

Tija, O. Setiawati, L. 2012. Effect of Accounting Conservatism to Value of the Firm: Study for Banking Industry in Indonesia. World Journal of Social Sciences. Vol 2 No 6 September 2012, pp: 169178.

Thohiri, R. 2013. Pengaruh Pengungkapan Konservatisme Akuntansi Terhadap Nilai Perusahaan Dengan Profitabilitas Sebagai Moderating Variabel Studi Empiris Pada Perusahaan LQ-45 yang Terdaftar di BEI Periode 2007-2010. Tesis. Medan: Universitas Sumatera Utara.

Wardhani, Ratna. 2008. Tingkat Konservatisme Akuntansi di Indonesia dan Hubungannya dengan Karakteristik Dewan Sebagai Salah Satu Mekanisme Corporate Governance. Simposium Nasional Akuntansi Pontianak.

Watt, Zimmerman. 1986. Conservatism in Accounting. The Bradley Policy Research Center Financial Research and Policy. Working Paper. No. FR 02-21.

Watts, 2002. Positive Accounting Theory. Englewood Cliffs, NJ: Prentice-Hall.

Watts, R.L. 2003. "Conservatism in Accounting Part I: Explanations and Implications", Journal of Accounting and Economics.

Widanaputra, A.A.G.P. 2007. Pengaruh Konflik antara Pemegang Saham dan Manajemen Mengenai Kebijakan Dividen terhadap Konservatisme Akuntansi. Disertasi, Program Doktor Akuntansi Fakultas Ekonomi, Universitas Gadjah Mada.

Widya, 2004, Analisis Faktor - Faktor yang Mempengaruhi Pilihan Perusahaan Terhadap Akuntansi Konservatif. Simposium Nasional Akuntansi VII, Denpasar.

Wirokosumo, D. Y. 2011. Pengaruh Konservatisme Akuntansi Terhadap Nilai Perusahaan Dan Profitabilitas Sebagai Moderator (Studi Empiris Pada Perusahaan-Perusahaan Yang Termasuk Dalam Indeks Sri Kehati). Yogyakarta: Universitas Atma Jaya. 
Journal of Management
and Business Roview

Yasa, Gerianta Wirawan. 2007. Manajemen Laba Sebelum Pemeringkatan Obligasi Perdana: Bukti Empiris dari Pasar Modal Indonesia. Disertasi. Fakultas Ekonomi Universitas Gadjah Mada, Yogyakarta. 